\title{
Chapter 11 \\ Politics of Inequality in Indonesia: Does Democracy Matter?
}

\author{
Koichi Kawamura
}

In a democracy, it is expected that not only political but also economic equality is achieved. Assuming that the median voter is the decisive voter under universal suffrage and majority rule, in a democratic polity, especially in developing countries where the poor exceed the rich in number, the income of the decisive voter is less than the mean income. Thus, the preference of the decisive voter on public policies is for higher income taxes on the rich and more fiscal redistribution (Meltzner and Richard 1981). More redistribution in turn reduces inequality. Although the relation between democracy and redistribution is not so straightforward, as argued by Meltzner and Richard (Acemoglu et al. 2013), there is at least a theoretical pathway from democracy towards redistribution.

Indonesia experienced a political transition from the thirty-two-year authoritarian regime under President Suharto to democracy in 1998. Since then, fundamental institutional reforms have been carried out, and free and fair elections for the central government have been conducted every five years since 1999, as well as for local governmental heads since 2005. In the same period, the Indonesian economy has also undergone major transformation. Although economic recovery from the Asian financial crisis was delayed for a decade, with GDP growth recovering to the precrisis level in 2006, Indonesia successfully managed to achieve approximately $6 \%$ growth on average between 2004 and 2014. Sustained economic growth has created a middle class that is stronger than ever before.

However, economic growth has not solved the issue of poverty. Although the national poverty rate steadily decreased during the decade of economic growth, income inequality also rose rapidly. This situation indicates that redistribution policies do not work to reduce economic inequality. Although Indonesia is recognized as a successful democratizing country, democracy does not bring about economic equality, in contrast to the abovementioned theory that democracy reduces inequality.

\author{
K. Kawamura ( $\varangle)$ \\ IDE-JETRO, Chiba, Japan \\ e-mail: koichi_kawamura@ide.go.jp \\ (C) The Author(s) 2019 \\ K. Tsunekawa and Y. Todo (eds.), Emerging States at Crossroads, \\ Emerging-Economy State and International Policy Studies, \\ https://doi.org/10.1007/978-981-13-2859-6_11
}


The period of stable economic growth provided the government with an opportunity to reduce economic inequality. The statistics, however, show the government could not take advantage of economic growth. Was the government not serious about tackling the rising inequality issue? If it was serious, why did its policy response fail to address the issue?

The government of Indonesia, in fact, has put a high priority on the issues of poverty and inequality. However, the policy responses have been insufficient to fulfill the financial as well as practical needs. Although policy implementations are always cited as a major obstacle to solving the socio-economic issues of this country, the low level of financial allocations are crucial for this matter. This is contradictory since financial allocation for redistribution should increase under a democratic government, especially in a country such as Indonesia, where the poor is majority of the population. Why did the government of Indonesia insufficiently allocate its budgets to antipoverty or anti-inequality policies?

The author argues that the fundamental reason lies in the system of political parties in Indonesia. Although democratic elections are regularly held and political parties play a central role in both electoral and legislative politics, the non-existence of massbased political parties is critical to the insufficient allocation of government resources to poverty eradication policies. Since most of the voters have lost party identification, becoming swing voters, parties have tended to rely on a small group of elites; as a result, there has been a rise of clientelistic politics and widespread corruption. In contrast, the popularly elected president has an incentive to redistribute the state resources to the lower strata of the population since he/she seeks nationwide support to win the elections. The policies of poverty reduction in Indonesia are, thus, decided on a nuanced balance between narrow-interest parties and wide-interest presidents.

The argument of this article goes as follows. In the first section, the author looks at poverty and inequality in Indonesia during the democratic period. This section is followed by a review of the government's policy response to the issue. In the third section, the author seeks to understand the reason for the lack of policy efforts by analyzing budgetary politics, arguing that no political parties sincerely tackle anti-poverty issues since their constituencies are not the poor. In the final section, I conclude the argument.

\subsection{Poverty and Inequality in Indonesia}

This article uses official data on poverty from the Central Statistics Agency (Badan Pusat Statistik: BPS). It is often noted that there are deficiencies in BPS's official poverty estimates. For example, BPS publishes poverty estimates based on household consumption, which is justified by the fact that consumption data are generally more reliable than income data and are a better indicator since individuals and households derive utility from expenditures rather than incomes (Nugraha and Lewis 2013, p. 104; Deaton 1997; Akita et al. 1999). BPS has used data from the National Socioeconomic Census (Statistik Sosial Ekonomi Nasional: Susenas) to estimate poverty 
and inequality, but the sampling methodology has changed so poverty estimates are not strictly comparable in a time series (World Bank 2016, p. 41). ${ }^{1}$ Despite the above deficiencies, BPS data are used in this article since it is not this chapter's intention to compare poverty in Indonesia with other countries by internationally used indicators.

Official BPS data show that Indonesia under Suharto's authoritarian rule succeeded in dramatically reducing the poverty population as well as the poverty rate (see Table 11.1). The number of poor individuals decreased from 70 million in 1970 to 22.5 million in 1996, just one year before the Asian financial crisis. The percentage of poor individuals in the total population also decreased from $60 \%$ in 1970 to $11.3 \%$ in 1996. The Asian financial crisis obviously reversed this trend, but data on poverty in 1997 were not available because of political and economic turmoil in this year. Furthermore, because of a change in the definition and method to measure poverty in 1996, data before and after 1996 are not comparable. Both the poverty population and poverty ratio, however, started to decline again in 1999. In particular, stable economic growth beginning in 2007 helped to reduce poverty. During the period of consecutive 6\% growth between 2007 and 2012, except for the year 2009 when the world financial crisis called "the Lehman shock" hit the country, the number of poor individuals declined more than 10 million. During the same period, the poverty ratio also decreased approximately 6\% points from $16.6 \%$ in 2007 to 11.96 in 2012 .

Inequality also improved during Suharto's rule, although the magnitude was not as significant as the achievements in poverty reduction. However, inequality began to rise after the late 1980s, when Suharto's developmentalism was gradually overwhelmed by the rise of his family businesses and crony capitalism. During the period of economic recovery from the Asian financial crisis and political democratization, this upward trend did not reverse. In 1999, the Gini coefficient declined to the same level as in the late 1980s, but thereafter it steadily rose. Inequality rose from 31 point in 1999 to 41 point in 2011 and has maintained that figure since then. The size of the increase in the Gini coefficient during this period was second only to China. The rising inequality of Indonesia is also exceptional since inequality was stable or decreased in neighboring countries such as Malaysia, Thailand, and Vietnam during the same period (World Bank 2016, p. 38). ${ }^{2}$

Considering that poverty is persistent and inequality rises, there are many things that the government can do. The government should redistribute economic benefits created by the commodities boom into lower classes and implement pro-poor policies in sectors such as social security, health, and education. Although the Indonesian government has implemented several poverty alleviation programs, the reality of

\footnotetext{
${ }^{1}$ A World Bank report points out that the sampling methodology changed so significantly in 2011 that the poverty and inequality series are not strictly comparable between 2010 and before 2011 and after (World Bank 2015, p. 41). See also Priebe (2016).

${ }^{2}$ The widening economic gap is economically attributed to the uneven distribution of benefits from economic growth. A World Bank report revealed incomes of richer households grow faster than those of the lower middle class (World Bank 2016). Then, it is argued that the uneven distribution of growth benefits was partly caused by the commodities boom in 2003-12. However, since rising inequality began well before the commodities boom in the 2000s, the commodities boom cannot explain the whole story of rising inequality in Indonesia.
} 


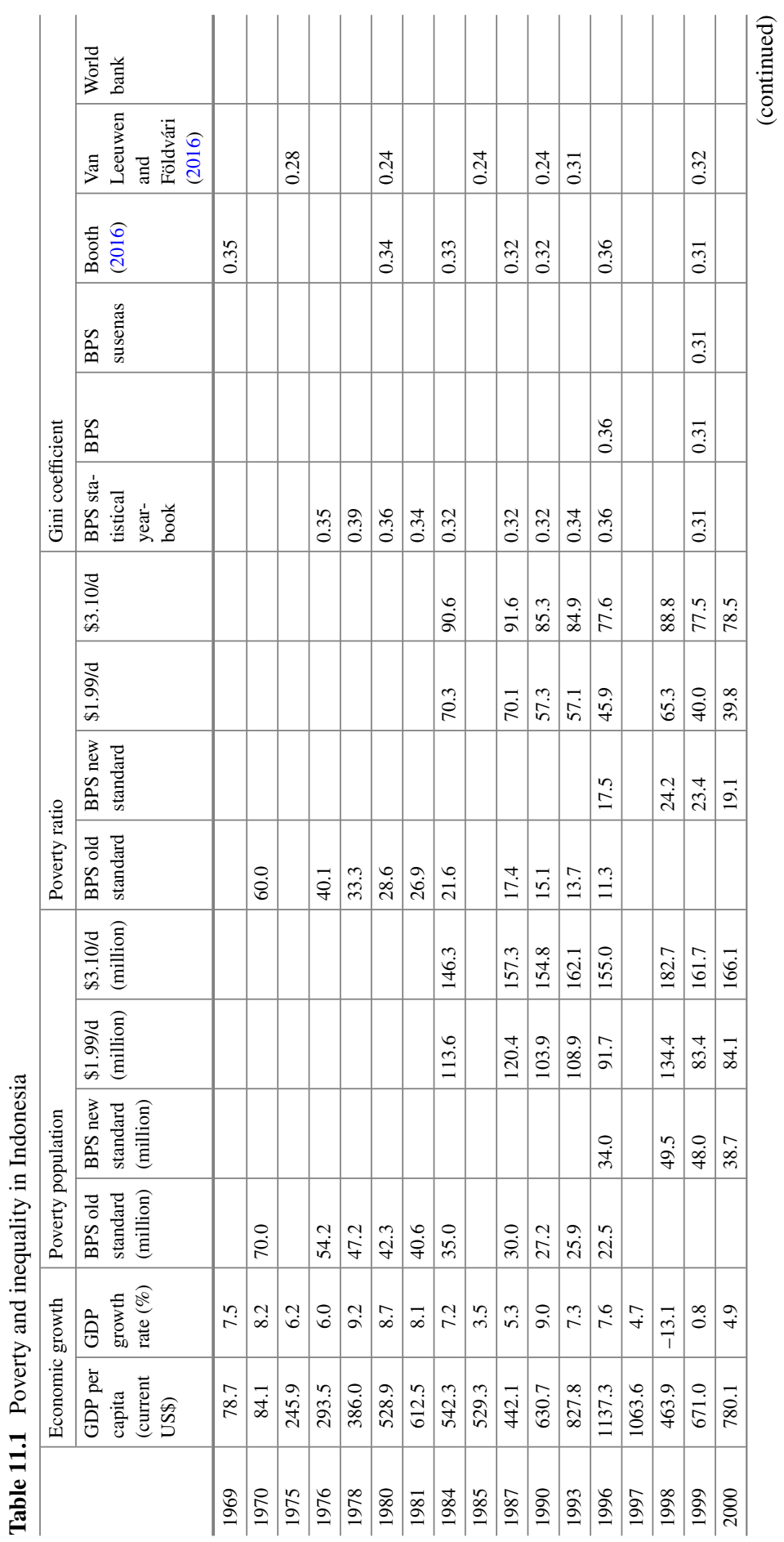




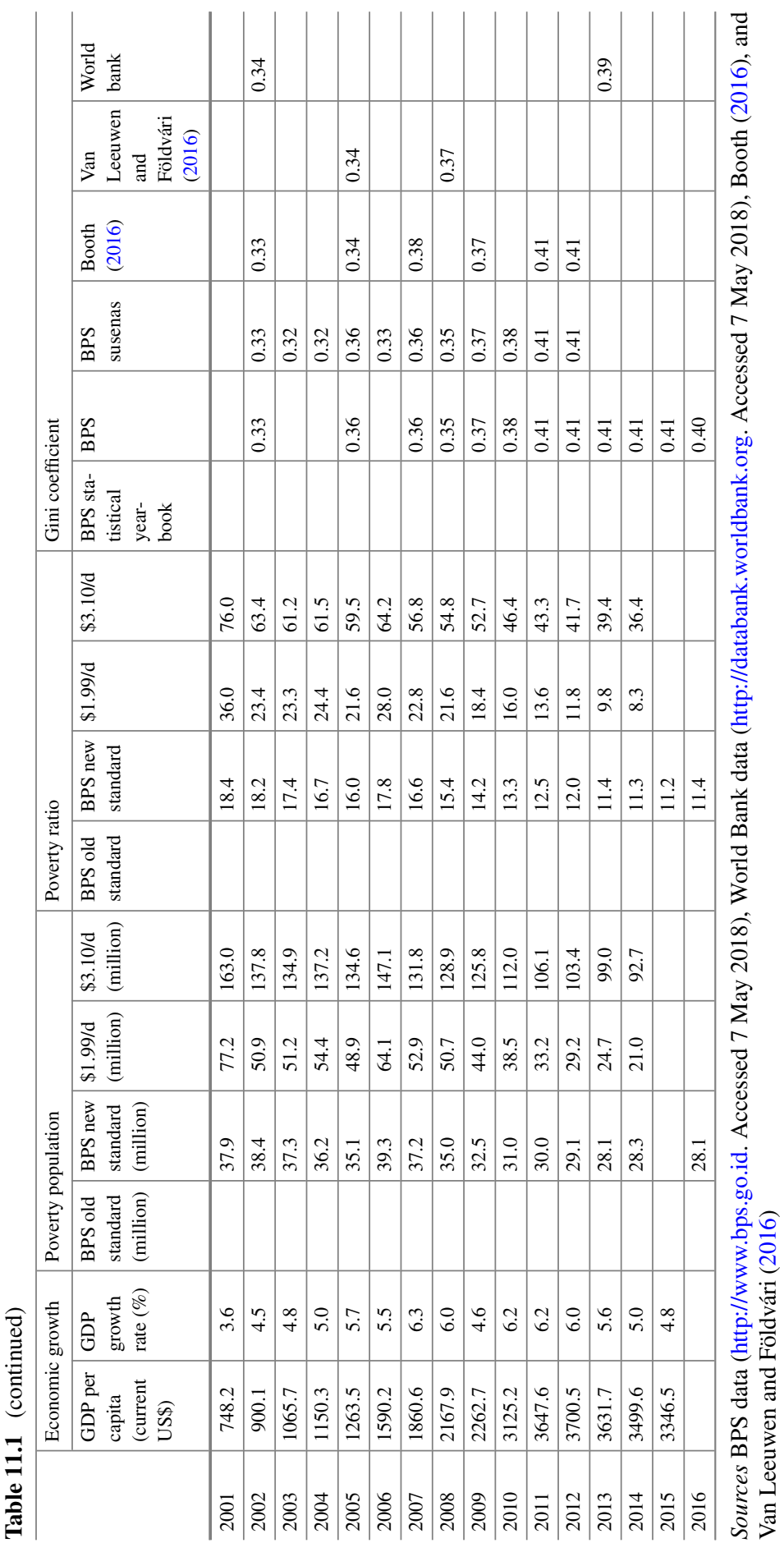


persistent poverty and rising inequality shows that those efforts have not met societal needs. A question arises here of what Indonesia's democratic government has done to confront economic disparities in society. In the next section, we look at what programs have been prepared by the government to alleviate poverty and what amount of growth benefits has been redistributed from the richer, who enjoy the most of them, to the poorer, who enjoy the least.

\subsection{Social Policies in Indonesia}

One of the policy responses to addressing the issue of inequality is fiscal policy. With competent public spending, governments can improve social welfare and reduce the number and depth of persons in poverty (van de Walle 1998). Many empirical studies also show that developing countries, such as Brazil and South Africa, have successfully used fiscal policy to reduce their level of inequality.

The government of Indonesia also has used fiscal policy in the form of poverty alleviation programs irrespective of its regime type. While the Suharto government gave priority to achieving high economic growth over the long term through agricultural development and industrialization, he realized the need to implement redistribution policies. ${ }^{3}$ Approximately a quarter of development expenditures on average were allocated to such sectors as village/regional development, education, health, social welfare, and housing through the first to fifth development plans between 1969 and 1994.

However, the Asian financial crisis starting in 1997 and the subsequent political transformation in 1998 made the existing poverty alleviation programs ineffective in implementation and impossible to continue. The existing programs could not respond to a sudden and sharp increase in the poverty. The top-down style of redistribution policy making and implementation also became impossible due to the step-down of President Suharto and fragile political environment during the democratization process.

Responding to changing political and economic environments, the Indonesian government launched a set of new social safety net programs called the JPS (Jaring Pengaman Sosial) in the summer of 1998. Many of these JPS programs, which were introduced with the aid of advanced donor countries, evolved into permanent programs in the government's poverty alleviation and social assistance strategy over the

\footnotetext{
${ }^{3}$ Under the Suharto government, redistribution polices were mainly implemented through the Presidential Instructions (Instruksi Presiden: Inpres) program with an aim to improve social infrastructure in rural areas. Programs for village/regional development and education were particularly prioritized, with an average of $10 \%$ shares in development expenditures during the same period (Sumodiningrat 2006, p. 107; Kawamura 2008, pp. 6-7). Economic technocrats, who were a major policy maker of liberalistic growth policies under the Suharto regime, took center stage in drawing up these various Inpres programs to improve people's social welfare (Kawamura 2008).
} 
next decade (World Bank 2012a, p. 10). ${ }^{4}$ Social assistance initiatives that originated from the JPS began to be financed by the government's own budget expenditures, expanded, and institutionalized to become permanent and national programs.

Under the Susilo Bambang Yudhoyono government, elected in 2004 and reelected in 2009, achievements in poverty alleviation and social welfare were formally placed as one of the main development goals. The government made the National Strategy of Poverty Eradication (Strategi Nasional Penanggulangan Kemiskinan: SNPK) in October 2005, indicating a strong commitment of the administration to poverty eradication issues and an effort to achieve the Millennium Development Goals (MDGs) set by the United Nations. The intended commitment was materialized in the National Medium-term Development Plan 2004-2009 (Rencana Pembangunan Jangka Menengah Nasional 2004-2009).

While Yudhoyono inherited a number of poverty alleviation programs that were introduced as social safety net programs by the previous administrations, his administration also expanded them and introduced a number of new ones (Wisnu et al. 2015, p. 328). One of key programs inherited from the social safety net program was the program of Rice for the Poor (Beras untuk Rakyat Miskin: Raskin), which has its origin in the Special Market Operation (Operasi Pasar Khusus: OPK) program starting in July 1998. Through this program, poor households can buy rice with subsidized prices.

Another large program originating from the crisis era is the community development program called the PNPM (Program Nasional Pemberdayaan Masyarakat). It started in 1998 when the government introduced the Subdistrict Development Program (Program Pemgembangan Kecamatan: PPK) with the support of loans from the World Bank to increase social welfare in rural areas by empowering local government and institutions with community participations. The success of PPK made the government expand the coverage sectors of the program as the PNPM Mandiri in 2007, reaching all subdistricts in the country by 2012.5

The original pro-poor policies under the Yudhoyono administration started responding to world oil price hikes and the accompanying fuel subsidy cuts introduced by the government facing fiscal deficits. The immediate policy response to fuel subsidy cuts was a non-conditional cash transfer program called Direct Cash Support (Bantuan Langsung Tunai: BLT). It was introduced in October 2005, providing the poorest $30 \%$ of households compensation cash support with no conditions

\footnotetext{
${ }^{4}$ The JPS programs included (1) the sale of subsidized rice to poor families, (2) scholarships for elementary and junior secondary students from poor families, (3) block grants to health centers and to schools (SBG) for operating expenses, (4) nutritional supplements for infants and children, (5) a set of labor-creation activities known collectively as padat karya (public works), and (6) a regional development scheme known as Pemberdayaan Daerah Mengatasi Dampak Krisis Ekonomi (PDMDKE), which provided funds directly to village-level representative bodies (Lembaga Ketahanan Masyarakat Desa: $L K M D$ ) for use on village-level projects that would contribute to economic resiliency (World Bank 2012a, p. 10).

${ }^{5}$ The PNPM program has become one of the largest schemes of its kind in the world. While considered more effective than several other anti-poverty programs, it has also been the target of criticism, related especially to the capture of programs by local elites and the lack of support from local governments (Miranti et al. 2013; McCarthy et al. 2014; Manning and Miranti 2015, p. 315).
} 
attached. The program was reintroduced in 2008 and 2013 when the government cut fuel subsidies in response to a rise in international oil prices.

The School Operational Assistance (Bantuan Operasional Sekolah: BOS) program was also introduced to mitigate a negative impact of fuel subsidy cuts in 2005 . The rise of fuel prices was anticipated to decrease the purchasing powers of poor households, which might have forced them to decrease education expenditures, leading to school dropout or termination of continued higher education for students from poor households. Through this program, the central government gives funds to primary and junior secondary schools to cut education fees for students from poor households and to support school-based management reforms.

A conditional cash transfer (CCT) program, which is widely used to eliminate poverty and improve inequality in developing countries, was introduced under the Yudhoyono administration. The program, called the Hopeful Families Program (Program Keluarga Harapan: $P K H)$, provides cash support to extremely poor families with obligations that family members are checked at local public clinics (Pusat Kesehatan Masyarakat: Puskesmas) or that their children attend school. After being introduced as a pilot program in 2007, it was gradually expanded in terms of coverage as well as budget allocations since it was considered effective by international standards and more efficient than other household-targeted programs (Yulaswati and Sumadi 2011; Manning and Miranti 2015, p. 314).

A move towards the establishment of universal health insurance also began under the Yudhoyono government. The existing social insurance scheme covered only civil servants, military and police officers, as well as formal sector employees, covering only $10 \%$ of the population (ILO 2008). There was only a small-scale health insurance scheme for the poor introduced as one of the social safety net programs at the time of the Asian financial crisis. The health insurance program for the informal sector and the poor was for the first time introduced in $2004,{ }^{6}$ renamed the next year as Health Insurance for the Poor Households (Asuransi Kesehatan untuk Keluarga Miskin: Askeskin), and expanded in 2008 to become Social Health Insurance (Jaminan Kesehatan Masyarakat: Jamkesmas). The premiums for health insurance were fully subsidized by a government health fund. Under this program, households receive comprehensive insurance coverage for public health care (Sparrow et al. 2013). ${ }^{7}$ As Universal Social Insurance (Sistem Jaminan Sosial Nasional: SJSN) began to be introduced in 2014, the Jamkesmas program was integrated into a part of the National Health Insurance scheme (Jaminan Kesehatan Nasional: JKN).

President Joko Widodo (popularly called “Jokowi”), elected in the 2014 election, also inherited and expanded poverty alleviation programs implemented under the ten-year Yudhoyono presidency (Yusuf and Sumner 2015). Soon after the inaugura-

\footnotetext{
${ }^{6}$ At the introduction of health insurance program in 2004, the program was called the Free Poor Health Services (Pelayanan Kesehatan Masyarakat Miskin Gratis).

${ }^{7}$ Along with Jamkesmas, local governments introduced their own complementary health insurance schemes for the poor. These schemes were known as the Regional Health Insurance (Jaminan Kesehatan Daerah: Jamkesda). They provided some coverage to those classified as poor or near poor but who were not covered by Jamkesmas. Some local governments also provided free health services for all (World Bank 2012b, p. 48).
} 
tion of new presidency, Jokowi declared the introduction of three new social welfare cards, the Smart Indonesiea Card (Kartu Indonesia Pintar: KIP), the Health Indonesia Card (Kartu Indonesia Sehat: KIS), and the Family Welfare Card (Kartu Keluarga Sejahtera: $K K S$ ). This showy event saw wide media attention since it was recognized as showing Jokowi's lower-class political support base and his commitment to the election campaign promises. However, all three cards, in fact, were modified programs already implemented by the previous Yudhoyono administration with different names: KIP was inherited from scholarships for students from poor households, the Poor Students Assistance program (Bantuan Siswa Miskin: BSM); KIS was inherited from the JKN program; and KKS was a replacement of the Social Protection Card (Kartu Perlindungan Sosial: PKS), which functioned as an ID card for poor households to receive various social welfare services, such as Raskin, BSM, and BLT. The BLT program was also renamed to become the Family Welfare Savings Program (Program Simpanan Keluarga Sejahtera: PSKS) with changes from cash payments to transfers to savings account. Other key programs such as BOK, PKH, and PNPM were also maintained under the Jokowi administration. His original redistribution policy was the Village Fund (Dana Desa), in which the central government directly distributed public funds to every village with the hope that those funds were utilized to realize community-based development and increase residents' welfare, but the deliberation of the law defining the Village Fund, the Law on Villages, took place during the Yudhoyono period.

In this way, Indonesia has been building and expanding a social assistance framework since the Asian financial crisis. Additionally, social assistance programs introduced after the crisis were not limited to those mentioned above. Notwithstanding, Indonesia still faces widespread poverty and rising inequality. Poverty and inequality problems remain partly because many of the social assistance programs were neither efficient nor effective. It is often criticized benefits as being too little, not reaching the right people, or not being received at the right time (World Bank 2016, pp. 113-14). The latter two problems are an issue of Indonesia's bureaucratic capabilities and efficiencies. However, the first problem, the amount of redistribution expenditures, is political: What amount of public spending is allocated to social welfare policies depends on the will of political leadership and legislative deliberations in the parliament. Why does Indonesian democracy fail to deliver enough benefits to the poor? Before analyzing this issue, we look at budget allocations to the social sector since democratization.

\subsection{Budget Allocations to Social Sectors}

Since democratization, every president of Indonesia has expressed, more or less, his/her commitment to poverty alleviation and a political will to reduce economic inequality, and, in reality, numerous policies and programs have been introduced and implemented. Nonetheless, they have never received enough spending in the annual budgets to be effective. 


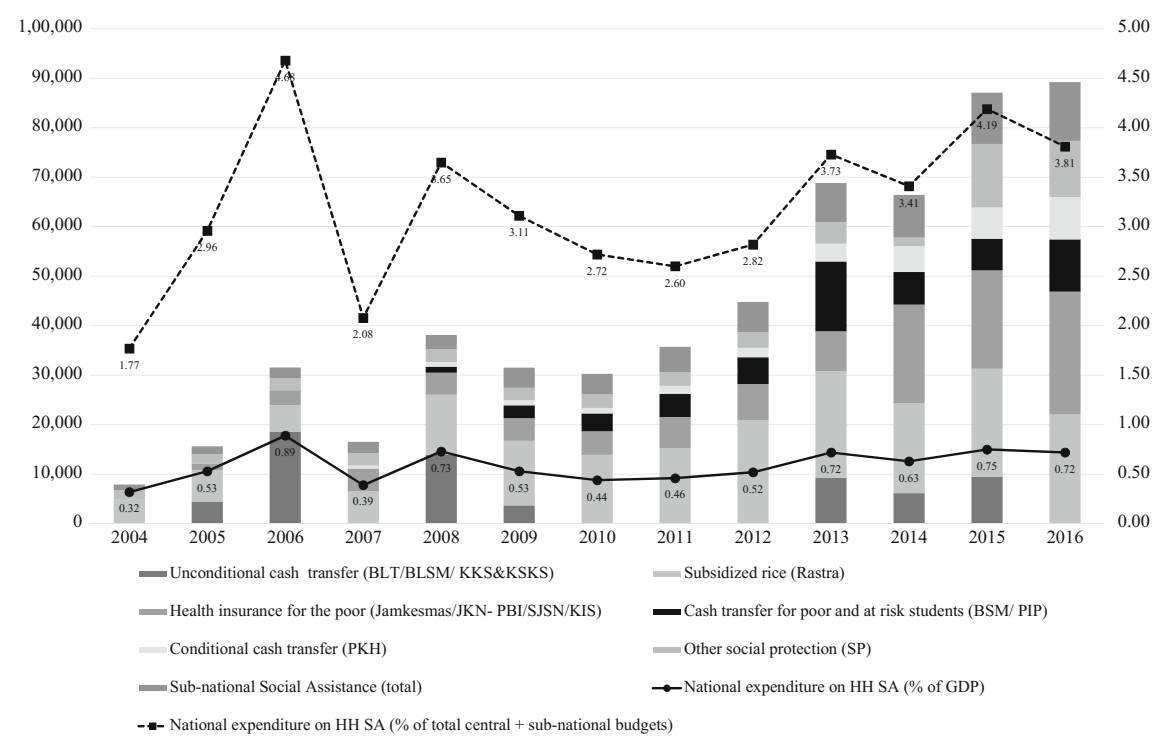

Fig. 11.1 Government expenditure on social assistance programs, 2004-16. Source World Bank (2017, p. 27)

In particular, social assistance programs, the most effective at reducing inequality, have received the least spending overall. Indonesia spends approximately 0.5 to $0.7 \%$ of GDP on social assistance (see Fig. 11.1). The inadequacy of this budget allocation is apparent if compared to other large middle-income countries, which spend, on average, three times as much on these programs (World Bank 2014, p. 144). Among social assistance programs, direct cash transfer programs, the most effective at reducing inequality, are allocated only less than $0.5 \%$ of GDP (World Bank 2016, pp. 135-36).

Health spending has also been among the lowest levels among developing countries until recently (see Fig. 11.2). Health expenditures have been only 2\% of GDP in Indonesia, much lower than the average of lower middle-income countries as well as neighboring countries in the region, such as Thailand, the Philippines, and Vietnam. Health expenditures claimed only $3 \%$ of total public spending during the second term of the Yudhoyono administration, and less than $2 \%$ of central government spending (see Table 11.2). The administration of President Jokowi increased the health budget in 2016 to $5 \%$ of total state spending. However, much of this increase is devoted to the establishment of the national health insurance system (JKN).

Expenditure on education has had a much larger share of national budgets than any other social spending. This is because the amended constitution provides at least 


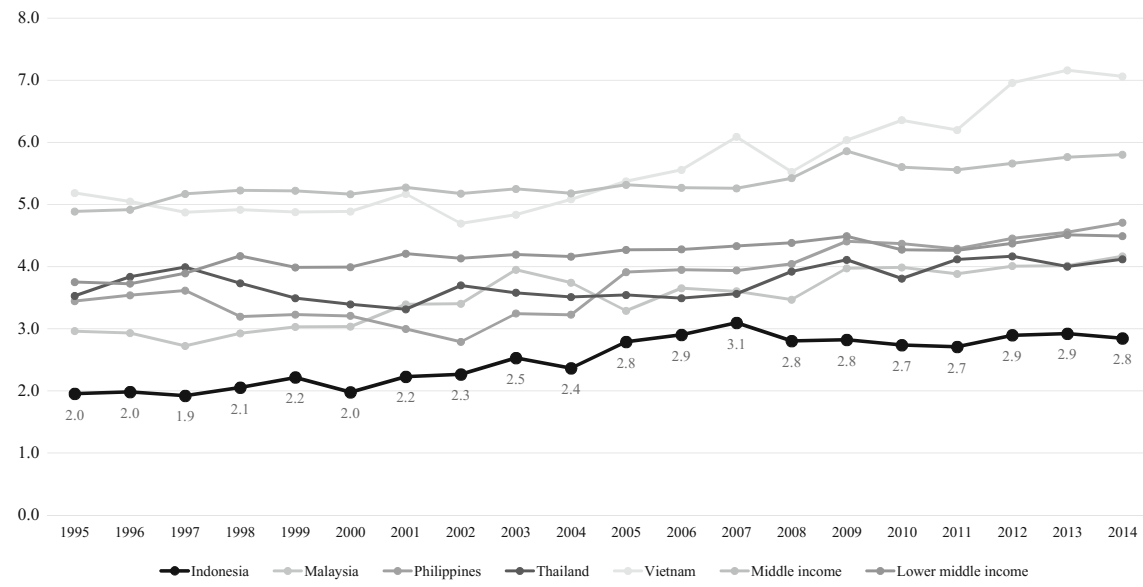

Fig. 11.2 Total health expenditure (\% of GDP). Source World Development Indicators. http:// databank.worldbank.org. Accessed 7 May 2018

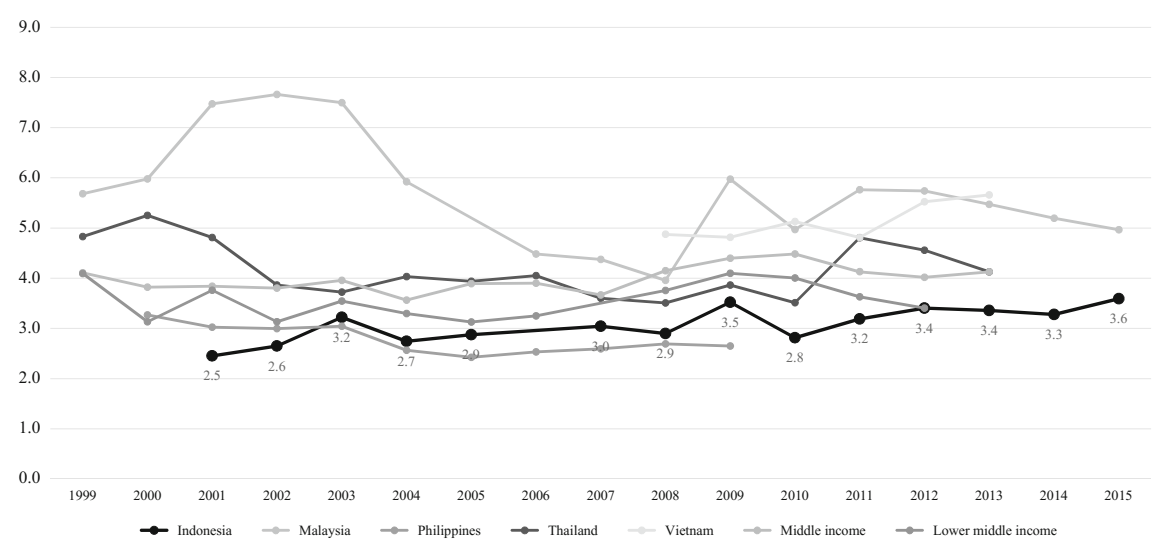

Fig. 11.3 Total education expenditure (\% of GDP). Source World Development Indicators. http:// databank.worldbank.org. Accessed 7 May 2018

$20 \%$ of budgetary allocations to the education sector. ${ }^{8}$ However, education spending has still been lower than the average of lower middle-income countries as well as neighboring countries in the region (see Fig. 11.3).

As such, none of the social sectors - social assistance, health, and education - has been given priority in the national budget of democratizing Indonesia. Then, which

\footnotetext{
${ }^{8} \mathrm{~A}$ provision of the budgetary requirement for the education sector was provided in the fourth amendment of the 1945 Constitution in 2002 . However, $20 \%$ of budgetary allocation to the education sector had not been attained until 2009. After the Constitutional Court ruled the less than $20 \%$ of allocation to the education sector was unconstitutional for four consecutive years between 2005 and 2008, the Yudhoyono administration finally fulfilled the constitutional requirement.
} 
Table 11.2 Budget for health and education sectors (trillion rupiah)

\begin{tabular}{l|l|l|l|l|l|l|l|l|l}
\hline & 2009 & 2010 & 2011 & 2012 & 2013 & 2014 & 2015 & 2016 & 2017 \\
\hline $\begin{array}{l}\text { National expenditure for } \\
\text { health }\end{array}$ & 27.8 & 28.8 & 39.4 & 41.5 & 48.2 & 61 & 74.8 & 104.1 & 104 \\
\hline $\begin{array}{l}\% \text { share of national budget } \\
(\%)\end{array}$ & 3.0 & 2.8 & 3.0 & 2.7 & 2.8 & 3.3 & 3.8 & 5.0 & 5.0 \\
\hline $\begin{array}{l}\text { Central government } \\
\text { expenditure for health }\end{array}$ & 23.2 & 25.2 & 35.4 & 37.3 & 43.8 & 56.4 & 63.5 & 76.1 & 75.2 \\
\hline $\begin{array}{l}\text { Local transfer expenditure } \\
\text { for health }\end{array}$ & 4.6 & 3.7 & 4 & 4.2 & 4.5 & 4.6 & 7.8 & 21.2 & 25.2 \\
\hline $\begin{array}{l}\text { Payment } \\
\begin{array}{l}\text { National expenditure for } \\
\text { education }\end{array}\end{array}$ & 0 & 0 & 0 & 0 & 0 & 0 & 3.5 & 6.8 & 3.6 \\
\hline $\begin{array}{l}\% \text { share of national budget } \\
\text { (\%) }\end{array}$ & 20.8 & 225.0 & 26.2 & 20.1 & 20.0 & 20.0 & 20.6 & 20.0 & 20.0 \\
\hline $\begin{array}{l}\text { Central government } \\
\text { expenditure for education }\end{array}$ & 90.6 & 96.5 & 105.4 & 117.2 & 126.2 & 128.2 & 154.4 & 145 & 145.4 \\
\hline $\begin{array}{l}\text { Local transfer expenditure } \\
\text { for education }\end{array}$ & 117.7 & 127.7 & 159 & 186.6 & 214.1 & 238.8 & 254.2 & 266.6 & 268.2 \\
\hline \begin{tabular}{l} 
Payment \\
\hline
\end{tabular}
\end{tabular}

Note Figure for 2009 is a realized expenditure. Figure for 2010 is an expenditure of the central budget. Figures for 2011-2017 are expenditures of the revised central budgets

Source Central annual budget for each year. https://www.kemenkeu.go.id/informasi-publik/uuapbn-dan-nota-keuangan. Accessed 10 May 2018

sector has been given priority in budgetary allocation? The largest allocation of budget spending has been subsidies, most of which is fuel subsidies (see Fig. 11.4). For instance, the 2012 spending on fuel subsidies of 212 trillion rupiah was equivalent to total central government spending on capital (140 trillion rupiah) and social expenditures (75 trillion rupiah) combined. It was three times the 2012 budget allocation to central government infrastructure spending (World Bank 2014, p. 57). However, energy subsidies are enjoyed more by richer households, which are more likely to have cars and motorcycles, than by poorer households (World Bank 2015, p. 19). In this sense, the fuel subsidy program is regressive and the least effective in reducing inequality (Resosudarmo and Yusuf 2009; Dartanto 2013; Yusuf et al. 2014; Manning and Miranti 2015).

Therefore, whereas many poverty alleviation programs and social assistance policies have been introduced by post-authoritarian administrations, budget allocations for social welfare have been mostly too small despite public as well as theoretical expectations to the contrary. To analyze this puzzle, the next section will examine the budgetary political process in Indonesia. 


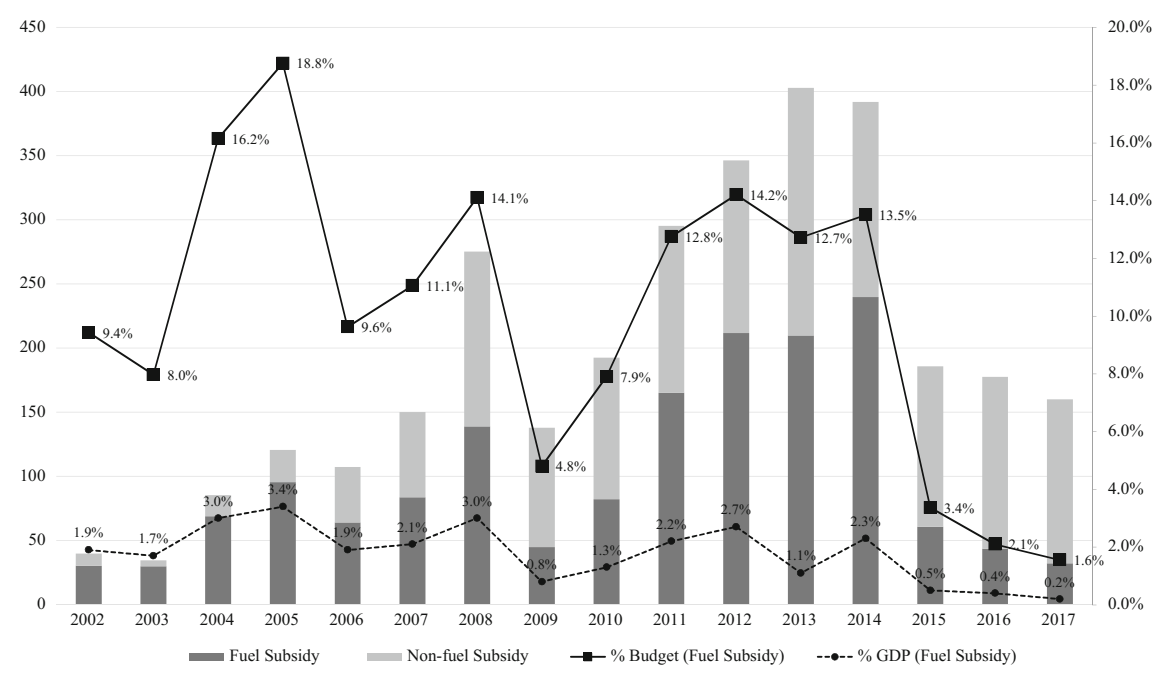

Fig. 11.4 Trends in fuel subsidy. Source Central annual budget for each year. https://www. kemenkeu.go.id/informasi-publik/uu-apbn-dan-nota-keuangan. Accessed 10 May 2018

\subsection{Budgetary Politics Under Indonesia's Democracy}

The deliberation on a draft of the central government budget begins in May when the government submits to the general assembly of the parliament (Dewan Perwakilan Rakyat: DPR) main points of a proposed budget, including predicted macroeconomic indicators, basic fiscal policy, and budget priorities. After reaching a consensus between the parliament and government on these matters by the end of June, the president submits a bill of the budget, budget guidelines, and supporting documents to the general assembly of the parliament a day before the Independence Day, 17 August. The budget committee and concerned committees discuss with ministers and other representatives from the government the details of budget proposals before approving it at the general assembly in October at the latest. At the deliberation of a budget draft, the parliament can make a proposal, which may change estimated revenue and expenditures, as well as discuss the details of the budget including organizational allocations, sectoral allocations, program and project allocations, and classifications of budget utilization. Thus, the parliament is given strong and expanded authority to propose changes in a budget draft from an annual budgetary framework to details of budgetary allocation.

Indonesia's parliament is given strong power vis-à-vis the president in not only the budgetary deliberation but also any discussions of bills. Another characteristic of Indonesia's parliament is that any bills are expected to be approved in accordance to the parliamentary ruling of consensus decision making, rather than majority voting (Kawamura 2013). This means that not only ruling parties but also opposition parties 
can claim changes in bills including the annual budget, and because the latter's opinions are treated equally, their demands can easily materialize in approved bills.

Considering these characteristics in Indonesia's parliament, any parties, whether ruling or opposition and whether large or small, can demand an increase in budgetary allocations to social policies and social assistance programs if they desire. Nonetheless, political parties have not endeavored to increase budgetary allocations to the social sector.

Table 11.3 compares sectoral allocations of central government expenditures between the proposed (Rancangan Anggaran Pendapatan dan Belanja Negara: $R A P B N$ ) and the approved budget bill (APBN). Between 2012 and 2017, social sectors such as health, education, and social security received added budget allocations after deliberation in the parliament but not at significant levels. The average added budgetary allocations received by social sectors as a result of parliamentary deliberations was $8 \%$ for the health sector, $7.1 \%$ for the education sector, and $1.3 \%$ for the social security sector (excluding 2016 as an exceptional year). ${ }^{9}$ The average increase in allocations between before and after the deliberations for the three sectors combined was $5.7 \%$ (excluding the social security sector in 2016). Compared with sectors such as the economy, and order and security, which were allowed more than a $20 \%$ increase on average each year during this period, the figure has not been high enough to solve the reality of severe poverty and persistent inequality.

What is striking is a consistency of sectoral shares in the central government budget, in particular for the social sectors, during this period. The share of the health sector in the central budget was only $1.8 \%$ on average, although there was a slight increase in the 2017 budget due to a change in program clarifications as well as the regulation of the Health Law. The share of the social security was less than one percent before 2016, when the introduction of the universal social insurance system began to add budget allocations to this sector. Likewise, although the education sector receives a large share of national expenditures because the constitution defines a minimum $20 \%$ allocation of national budget expenditures and the constitutional court ruling demands it be fulfilled, it has consistently received $10 \%$ of the central government expenditure. $^{10}$

\footnotetext{
${ }^{9}$ The health and education sector in 2016 saw a sharp increase in budget allocations, but they were exceptional. The increase in health sector allocation in 2016 was due to a change in the classification of programs, which moved some programs from the other categories to the health sector. It was also due to the administration's intention to follow the regulation of the Health Law (Law No. 36 Year 2009), which regulates that budget allocation to the health sector must be above five percent of the central budget and $10 \%$ of the provincial, district, and city government budgets. The large increase in the social security sector's allocation in 2016 was due to a change in the classification of programs, which moved programs such as pensions and health insurances for civil servants, police, and military officers from other sectors.

${ }^{10}$ In Table 11.3, the average share of the education sector is only approximately $10 \%$, far less than the $20 \%$ constitutional requirement, partly because the functional categorizations of a budget document are not equal to the "education" budget (e.g., personnel salaries are not included in the functional category of education budget) and partly because education expenditures at local-level government budgets are not included here.
} 
Table 11.3 Comparison of social sector budgetary allocation between before and after deliberation

\begin{tabular}{|c|c|c|c|}
\hline & $\begin{array}{l}\text { Share before } \\
\text { deliberation }(\%)\end{array}$ & $\begin{array}{l}\text { Share after } \\
\text { deliberation }(\%)\end{array}$ & $\%$ Increase $(\%)$ \\
\hline \multicolumn{4}{|l|}{2012} \\
\hline Health & 1.54 & 1.61 & 5.9 \\
\hline Education & 10.02 & 10.74 & 8.4 \\
\hline Social security & 0.55 & 0.58 & 6.0 \\
\hline \multicolumn{4}{|l|}{2013} \\
\hline Health & 1.46 & 1.52 & 5.0 \\
\hline Education & 9.54 & 10.26 & 9.0 \\
\hline Social security & 0.65 & 0.64 & 0.7 \\
\hline \multicolumn{4}{|l|}{2014} \\
\hline Health & 0.99 & 1.05 & 7.6 \\
\hline Education & 10.79 & 10.51 & -1.1 \\
\hline Social security & 0.65 & 0.65 & 0.1 \\
\hline \multicolumn{4}{|l|}{2015} \\
\hline Health & 1.50 & 1.52 & 2.1 \\
\hline Education & 8.66 & 10.51 & 22.5 \\
\hline Social security & 0.60 & 0.60 & 0.2 \\
\hline \multicolumn{4}{|l|}{2016} \\
\hline Health & 0.36 & 0.47 & 27.4 \\
\hline Education & 6.89 & 7.16 & 2.7 \\
\hline Social security & 0.76 & 7.54 & 874.4 \\
\hline \multicolumn{4}{|l|}{2017} \\
\hline Health & 4.71 & 4.69 & 0.0 \\
\hline Education & 10.82 & 10.88 & 1.0 \\
\hline Social security & 12.09 & 11.99 & -0.5 \\
\hline \multicolumn{4}{|l|}{ Average for $2012-2017$} \\
\hline General services & 53.88 & 48.90 & -10.9 \\
\hline Defense & 6.62 & 6.91 & 5.2 \\
\hline Order and security & 3.68 & 4.52 & 27.1 \\
\hline Economy & 12.15 & 13.78 & 20.7 \\
\hline Tourism & 0.31 & 0.29 & -3.6 \\
\hline Religion & 0.53 & 0.64 & 23.1 \\
\hline Environmental protection & 0.95 & 1.35 & 45.7 \\
\hline Housing and public utilities & 1.97 & 2.00 & 2.0 \\
\hline Health & 1.76 & 1.81 & 8.0 \\
\hline Education & 9.45 & 10.01 & 7.1 \\
\hline
\end{tabular}


Table 11.3 (continued)

\begin{tabular}{l|l|l|c}
\hline & $\begin{array}{l}\text { Share before } \\
\text { deliberation (\%) }\end{array}$ & $\begin{array}{l}\text { Share after } \\
\text { deliberation (\%) }\end{array}$ & \% Increase (\%) \\
\hline Social security & 2.55 & 3.67 & 146.8 \\
\hline $\begin{array}{l}\text { (Social security excluding the 2016 } \\
\text { budget allocation) }\end{array}$ & & & 1.3 \\
\hline $\begin{array}{l}\text { Social sectors (health +education + } \\
\text { social security) }\end{array}$ & 4.59 & 5.16 & 54.0 \\
\hline $\begin{array}{l}\text { (Social sectors excluding the 2016 } \\
\text { social security budget allocation) }\end{array}$ & & & 5.7 \\
\hline
\end{tabular}

Source Central annual budget for each year. https://www.kemenkeu.go.id/informasi-publik/uuapbn-dan-nota-keuangan. Accessed 10 May 2018

In Indonesia's parliament, a draft budget always faces revisions proposed by political parties, and there has been no case where a submitted budget draft was approved by the parliament without any changes. As a result of deliberations, expenditure for the government apparatus tends to be cut whereas other sectors gain additional expenditures. ${ }^{11}$ The parliament is likely to add budgets to political (the order and security) or economic sectors (the economy), rather than to social sectors. Why did political parties in the parliament show no concern towards budgetary allocations to the social sectors and its expected increase in social welfare?

One of the reasons is the lack of political forces that truly represent the interest of the lower class. Until 1965, there was one of the strongest communist parties, the Indonesian Communist Party (Partai Komunis Indonesia: PKI), in Asia, holding large support bases among laborers and rural peasants. After the failed coup attempt on 30 September 1965, however, PKI and its members were physically destroyed by the military and Islamic paramilitarists and totally banned either as a political party or as political ideology.

Furthermore, President Suharto, who acquired the ruling power from Sukarno in 1966, restricted any political parties from establishing local branches below districts with the aim of not allowing the construction of a support base for anything except for his own ruling party, the Functional Group (Golongan Karya: Golkar). The government broke off the relationship between political parties and the general public, making the people demobilized "floating mass".

The broken relationship between parties and the public was not restored even after democratization in 1998. That political parties' lost relationship with constituencies can be observed in opinion polls. A poll survey reveals that approximately $80 \%$ of electorates do not have any particular party IDs since the democratization period (Indicator 2016). ${ }^{12}$ Those who lose their party IDs tend to swing their votes from one

\footnotetext{
${ }^{11}$ The Law on the State Budget (Law No. 17 Year 2003) regulates that the budget deficit must be less than three percent of GDP, so the parliament cannot increase expenditures at their will.

${ }^{12}$ A poll survey conducted by Indikator (2016) showed those who had a particular party identification were only 10-20\% of electorates during the period of 2011-2016. Surveys showed a trend
} 
party to another as elections are held, reflecting political and economic conditions at the time of elections. ${ }^{13}$

Since most electorates have weak partisanship, it is costly for political parties to organize them as a party constituency. Parties would rather rely on mobilizing voters' sentiments by using mass media and, more recently, the internet. In addition, parties have chosen an easy way to build and consolidate their organizational structure by recruiting party candidates and cadres from middle to upper classes, such as entrepreneurs, business persons, and Islamic leaders, rather than by growing younger activists. ${ }^{14}$ As opposed to those from the upper and middle classes who are able to be politically better organized and easily mobilized since they have financial as well as social resources, those from the lower class remain disconnected from any political forces. Even the Indonesian Democratic Party of Struggle (Partai Demokrasi Indonesia Perjuangan: PDIP), the party claiming to represent the lower class, or small people (partai wong cilik), is not necessarily chosen by a particular social class (Kawamura and Higashikata 2009) and their legislators come from the middle class (Morishita 2010). Therefore, the interests of the lower class are under-represented in the political arena due to the lack of mass-based political parties, whereas the well-organized upper and middle classes are over-represented.

\subsection{Politics of Fuel-Subsidy Cuts Under the Yudhoyono Presidency}

The budgetary process begins in the government since only the president has the authority to propose a draft budget, and the government is the sole agency to administer a budget. If a president has a policy orientation towards increasing people's welfare, he/she can make pro-poor policies and propose a draft budget emphasizing more the aspect of redistribution. Considering the presidential election system, a presidential candidate should have more incentive to redistribute economic benefits to the poor and increase their welfare. Different from the parliamentary election, where a proportional representative system is adopted, a president is elected by majority vote. In a country where the medium voter belongs to the poor, a candidate should have a

\footnotetext{
of Indonesian electorates increasingly losing party IDs since democratization. The percentage of those who had a party ID in 2003-2004 was around 50\% during the period of the second postdemocratization legislative elections and the first direct presidential election in 2003-2004, but thereafter continued to drop to $15 \%$ in 2008 (LSI 2008). Recently, the number of people who have a party ID has not increased, even in the election campaign period.

${ }^{13}$ Increasing swing voters are closely related to increasing numbers of political parties in the legislature and high electoral volatility. The rate of electoral volatility, or the net electoral change in the party vote between two consecutive elections, for example, was 23.0 in the 2004 general elections, increased to 28.7 in 2009, and maintained its level in 2014 at 26.3 (Higashikata and Kawamura 2015, p. 7).

${ }^{14}$ Morishita (2010) reveals that legislators at the post-democratization period are derived from the business sector, families of political elites, and the middle class.
} 
pro-poor policy if he/she wants to win electoral supports from the lower class. After being elected as a new president, he/she continues to have an incentive to commit to his/her electoral promise to help the poor to win reelection in the future.

In fact, Yudhoyono, the first popularly elected president in Indonesian history, followed this line of thinking. He expanded social safety net programs as well as introduced new social programs, meaning he had at least a political will to commit to pro-poor policy, although most of the programs lacked enough financial supports to be effective at reducing poverty and inequality. The insufficient budgetary allocation to the social sector was caused not by his political will but by the failure of policy change. Specifically, the least pro-poor program (or the most anti-poor program) had the largest allocation in budgets, and under the condition of limited financial resources, an increase in allocations to the social sector was impossible without the removal of fuel subsidies. Although government officials recognized that financial reallocation was necessary, it was politically difficult because many political parties oppose subsidy cuts, reflecting the fact that beneficiaries of fuel subsidies, the middle to upper classes, could voice their opinion much louder in the parliament as well as on the street than the lower class.

As discussed above, subsidies are the single largest item in the annual central budget, ranging from 15 to $25 \%$ of the total state expenditures. Among subsidies, fuel subsidies are the largest, ranging from 5 to $20 \%$ of the total expenditures, depending on the fluctuation of international oil prices. All of the post-democratization administrations recognized the need to reform the fuel subsidy system, partly because the IMF demanded the removal of fuel subsidies as a condition for loan disbursement and partly because Indonesia gradually changed from a net exporter to a net importer of oil, meaning that the oil price hike directly leads to rising fuel subsidies. B. J. Habibie, Abdurrahman Wahid, and Megawati Sukarnoputri, all of the successive presidents after democratization, gradually attempted to make domestic fuel prices close to the international market price and to reduce the fiscal burden of fuel subsidies (Beaton et al. 2017, p. 151).

President Yudhoyono also recognized fuel-subsidy spending was counterproductive, consuming state revenue that might be used for more productive purposes, such as infrastructure development and social welfare spending. In 2005, when the hike in international oil prices brought about a rise in fuel subsidy spending beyond the budget presumption, the Yudhoyono administration faced a possible fiscal crisis and a serious threat to Indonesia's macroeconomic stability. Yudhoyono hesitantly decided to raise domestic oil prices by cutting fuel subsidies in March and October 2005 after he resisted the move for several months despite a strong recommendation from his economic team (Liddle 2005, p. 335). In both cases, opposing voices also arose in the parliament before finally approving fuel subsidy cuts; in March, the nationalist opposition parties along with an Islamic partner party in the ruling coalition opposed the government and in September PDIP and small Islamic partner parties in the ruling coalition rejected a revision of the budget.

Yudhoyono was fully aware of political risks involved since the last move of this kind in May 1998 led to a massive protest on the street against the Suharto government and finally the collapse of his authoritarian regime. To ease public resentment against 
fuel price hikes, the Yudhoyono administration prepared a massive non-conditional cash transfer program, BLT, as well as other small pro-poor programs, targeting poor households, to compensate for the higher costs of public transport and kerosene use for cooking and lighting. ${ }^{15}$

The Yudhoyono government decided to increase domestic fuel prices again in 2008 in response to the sharp rise in the international oil prices. At this time, Yudhoyono reluctantly responded because he was worried about the possible repercussions from the public; therefore, his administration decided to implement the BLT program again in a more efficient and transparent manner, along with other pro-poor programs, such as subsidized rice, loans for small businesses, and educational support for the lower-ranking civil servants and military families (Beaton et al. 2017, p. 158). Against the government policy to raise fuel prices, the parliament decided to exercise its right to investigate state affairs (hak angket), but the move was not completed after the public seemed to accept price hikes.

In 2012, the Yudhoyono administration again had to consider raising domestic fuel prices due to an increase in international oil prices. Yudhoyono again faced opposition from the parliament, including coalition partners, which ultimately rejected the government proposal of rising domestic fuel prices. Instead, the parliament approved the conditional possibility of raising fuel prices if international oil prices rose above a certain level. The government also faced a number of large public demonstrations, some of which turned violent.

In 2013, Yudhoyono once again faced a fiscal crisis brought about by rising oil prices in the international market. Combined with an unconditional cash transfer program (Bantuan Langsung Sementara Masyarakat: BLSM), the improved and renamed BLT program, as well as many other social compensation programs, the government proposed a revised budget proposal that incorporated fuel subsidy cuts. There were fierce oppositions from nationalistic opposition parties as well as a small Islamist partner party in the ruling coalition before the parliament approved the revised budget by majority vote (Nehru 2013, p. 151).

During the ten-year term of President Yudhoyono, the government succeeded in cutting fuel subsidies four times in response to the rise in international oil prices and possible fiscal crisis. The successes in raising fuel prices had significant meaning since fuel price hikes were considered politically dangerous before the Yudhoyono presidency. Through the course of public debates and political negotiations, the notion that fuel subsidies were regressive in nature and counterproductive for economic development was shared in society, and the general public gradually accepted the policy that expenditures for fuel subsidies should be used for pro-poor programs.

Nonetheless, each time the government announced its intention to raise fuel prices, public protests as well as strong oppositions from the parliament arose. President Yudhoyono always had to address public opinions and negotiate with political parties

\footnotetext{
${ }^{15}$ Small compensation policies introduced at this time other than BLT were Askeskin, BOS, and the Village Infrastructure program (Infrastruktur Perdesaan: IP), which gave low-income and remote villages direct grants to improve infrastructure and generate temporary employment (Beaton and Lontoh 2010).
} 
not only from the opposition camp but also within the ruling coalition. Therefore, Yudhoyono could not completely remove fuel subsidies as a fundamental solution; rather, he cut subsidies at a minimum amount on an ad hoc basis in response to oil price hikes.

\subsection{The Rise of Populist President and Redistribution}

President Jokowi, only two months after the inauguration in October 2014, announced a sweeping reform of fuel subsidies; after deciding to raise fuels prices in November 2014, he announced at the end of the year the complete removal of gasoline subsidies in the Java, Madura, and Bali areas, the removal of all gasoline subsides in other areas except those related to distribution costs, and the introduction of a fixed price diesel subsidy (Beaton et al. 2017, pp. 162-67). Before the announcement of fuel price hikes, he announced the introduction of three social welfare cards, KIS, KIP, and $\mathrm{KSKS}$, as compensation programs. Jokowi told the public that budget expenditure saved from the abolition of fuel subsidies would be used for social welfare programs and infrastructure development. The public generally showed their acceptance to this sudden move, and the parliament did not show open objections despite there being sporadic protests on the street and some parliamentary members discussing their concerns. This is partly because fuel prices were decreased when the government announced the removal of fuel subsidies in December 2014. Thus, Jokowi seized the opportunity to announce a fundamental subsidy system reform that might cause political and public oppositions during a time of decreasing international oil prices, as observed in other fuel-subsidizing countries such as Malaysia and India (Beaton et al. 2017, p. 165).

More importantly, the reason why Jokowi took the decisive move to eliminate fuel subsidies is that his political support base is from the middle to lower classes. Jokowi is the first president who was born from the general public, not from the traditional ruling elite. He was originally a local furniture businessman, advancing his political career from the city mayor of central Java, Surakarta, and the governor of the national capital, Jakarta. His political style is different from the traditional elite in the sense that he is against the traditional interest structure, willing to reform the government to become more pro-people and pro-poor. Since the election campaign period, Jokowi made public his promise to reform fuel subsidies and reallocate expenditures to the social sectors and rural development. Thus, Jokowi is the first president who is explicitly a populist politician, having his constituencies in the middle to lower classes. Because he represents the interests of the lower classes, Jokowi could begin to reform the fuel subsidy system embedded in the existing elite interests. 


\subsection{Conclusion}

This chapter tries to answer the question of persistent inequality under a democratic regime by looking at the Indonesian case. The author hypothesized that one of the reasons that the government has failed to allocate sufficient budgets to effective poverty eradication programs is the lack of mass-based political parties in Indonesia's party system and representation of the lower class. The author analyzed parties' indifference to poverty and inequality by looking at legislative deliberations on annual budgets in the parliament. In addition, the author noted that the popularly elected president has an incentive to reallocate state resources to the lower class because he/she seeks to acquire political support from the majority of the population to win elections. The introduction of the popularly elected presidential system has created an opportunity for Indonesia to establish a government more concerned with people's welfare, especially the social and economic conditions of the lower class. Notwithstanding, the parliament is still occupied by political parties that lack the capabilities and incentives to organize a political support base at the lower strata of society, resulting in prevalence of clientelistic politics and corruption. The politics of inequality in Indonesia, thus, will be fought between these contrasting political institutions.

\section{References}

Acemoglu, Daron, Suresh Naidu, Pascual Restrepo, and James Robinson. 2013. Democracy, Redistribution and Inequality. NBER Working Paper No. 19746. Cambridge, MA: National Bureau of Economic Research.

Akita, Takahiro, Rizal Affandi Lukman, and Yukino Yamada. 1999. Inequality in the Distribution of Household Expenditures in Indonesia: A Theil Decomposition Analysis. The Developing Economies 37 (2): 197-221.

Beaton, Christopher, and Lucky Lontoh. 2010. Lessons Learned from Indonesia's Attempts to Reform Fossil-Fuel Subsidies. Report of the Global Subsidies Initiative and International Institute for Sustainable Development, Geneva.

Beaton, Christopher, Lucky Lontoh, and Matthew Wai-Poi. 2017. Indonesia: Pricing Reforms, Social Assistance, and the Importance of Perceptions. In The Political Economy of Energy Subsidy Reform, ed. Gabriela Inchauste and David G. Victor, 133-208. Washington, D.C.: The World Bank.

Booth, Anne. 2016. Economic Change in Modern Indonesia: Colonial and Post-Colonial Comparisons. Cambridge: Cambridge University Press.

Dartanto, Teguh. 2013. Reducing Fuel Subsidies and the Implication on Fiscal Balance and Poverty in Indonesia: A Simulation Analysis. Energy Policy 58: 117-134.

Deaton, Angus. 1997. The Analysis of Household Surveys: A Microeconomic Approach to Development Policy. Baltimore, MD: Johns Hopkins University Press.

Higashikata, Takayuki, and Koichi Kawamura. 2015. Voting Behavior in Indonesia from 1999 to 2014: Religious Cleavage or Economic Performance? IDE Discussion Paper No. 512. Chiba: Institute of Developing Economies.

ILO (International Labour Organization). 2008. Social Security in Indonesia: Advancing the Development Agenda. Jakarta: ILO. 
Indikator. 2016. Kinerja Pemerintahan Jokowi Pasca Reshuffle Jilid-2 (Achievements of Jokowi Government After the Second Cabinet Reshuffle). http://indikator.co.id/agenda/details/29/RilisSurnas-Kinerja-Pemerintahan-Jokowi-Pasca-Reshuffle-Jilid-2. Accessed on 26 Jan 2017.

Kawamura, Koichi. 2008. Indonesia's Development Policy in Historical Perspective. Background Paper No. 2 for JICA-IDE Joint Workshop on Indonesia's Development Strategy and Future Direction of JICA's Assistance in Indonesia. Jakarta: Japan International Cooperation Agency Indonesia Office.

Kawamura, Koichi. 2013. President Restrained: Effects of Parliamentary Rule and Coalition Government on Indonesia's Presidentialism. In Presidents, Assemblies and Policy-Making in Asia, ed. Yuko Kasuya, 156-193. Basingstoke: Palgrave Macmillan.

Kawamura, Koichi, and Takayuki Higashikata. 2009. Indonesia: saiseishita kiretsu tohyo to humeiryo na gyoseki tohyo (Indonesia: Resurgence of Cleavages and Ambiguity of Retrospective Voting). In Ajia kaihatsu tojosyokoku no tohyo kodo (Voting Behavior in Asian Democracies: Cleavages and the Economy), ed. Yasushi Hazama, 265-327. Chiba: Institute of Developing Economies.

LSI (Lembaga Survei Indonesia). 2008. Kecenderungan Swing Voter Menjelang Pemilu Legislatif 2009 (Trends of Swing Voters Towards Legislative Elections of 2009). http://www.lsi.or.id. Accessed on 17 Nov 2009.

Liddle, R.William. 2005. Year One of the Yudhoyono-Kalla Duumvirate. Bulletin of Indonesian Economic Studies 41 (3): 323-338.

Manning, Chris, and Riyana Miranti. 2015. The Yudhoyono Legacy on Jobs, Poverty and Income Distribution: A Mixed Record. In The Yudhoyono Presidency: Indonesiea's Decade of Stability and Stagnation, ed. Edward Aspinall, Marcus Mietzner, and Dirk Tomsa, 303-324. Singapore: Institute of Southeast Asian Studies.

McCarthy, John F., Dirk Steenbergen, Greg Acciaioli, Geoff Baker, Anton Lucas, Vivianti Ramble, and Carol Warren. 2014. Dilemmas of Participation: The National Community Empowerment Program. In Regional Dynamics in a Decentralized Indonesia, ed. Hal Hill, 233-259. Singapore: Institute of Southeast Asian Studies.

Meltzer, Allan H., and Scott F. Richard. 1981. A Rational Theory of the Size of Government. Journal of Political Economy 89 (5): 914-927.

Miranti, Riyana, Yogi Vidyattama, Erick Hansnata, and Rebecca Cassells, and Alan Duncan. 2013. Trends in Poverty and Inequality in Decentralising Indonesia. OECD Publishing.

Morishita, Akiko. 2010. 2009 nen kokkai giin ni miru Indonesia no seito seijika to seito no yakuwari (Changes in Political Parties and Politicians in Indonesia: An Observation of Elected Legislators in 2009 General Elections). In 2009 nen Indonesia no senkyo: Yudhoyono saisen no haikei to dai 2 ki seiken no tenbo (The 2009 General Elections of Indonesia: Analysis of Yudhoyono's Reelection and Prospect for His Second Administration), ed. Jun Honna and Koichi Kawamura, 91-108. Chiba: Institute of Developing Economies.

Nehru, Vikram. 2013. Survey of Recent Developments. Bulletin of Indonesian Economic Studies 49 (2): 139-166.

Nugraha, Kunta, and Phil Lewis. 2013. Towards a Better Measure of Income Inequality in Indonesia. Bulletin of Indonesian Economic Studies 49 (1): 103-112.

Priebe, Jan. 2016. How Robust Is Indonesia's Poverty Profile? Adjusting for Differences in Needs. Bulletin of Indonesian Economic Studies 52(2): 229-48.

Resosudarmo, Budy P., and Arief A. Yusuf. 2009. Survey of Recent Developments. Bulletin of Indonesian Economic Studies 45 (3): 287-315.

Sumodiningrat, Gunawan. 2006. Responsi Pemerintah Terhadap Kesenjangan Ekonomi: Studi Empiris Pada Kebijakan Dan Pembangunan Dalam Rangka Pemberdayaan Masyarakat (Government Response to Economic Disparity: Empirical Study on Policy and Development in Social Empowerment). Jakarta: PerPod.

Sparrow, Robert, Asep Suryahadi, and Wenefrida Widyanti. 2013. Social Health Insurance for the Poor: Targeting and Impact of Indonesia's Askeskin Programme. Social Science and Medicine 96: 264-271. 
Van de Walle, Dominique. 1998. Assessing the Welfare Impacts of Public Spending. World Development 26 (3): 365-379.

Van Leeuwen, Bas, and Péter Földvári. 2016. The Development of Inequality and Poverty in Indonesia, 1932-2008. Bulletin of Indonesian Economic Studies 52 (3): 379-402.

Wisnu, Dinna, Faisal Basri, and Gatot Arya Putra. 2015. Ambitious But Inadequate: Social Welfare Policies under Yudhoyono. In The Yudhoyono Presidency: Indonesia's Decade of Stability and Stagnation, ed. Edward Aspinall, Marcus Mietzner, and Dirk Tomsa, 325-344. Singapore: Institute of Southeast Asian Studies.

World Bank. 2012a. History and Evolution of Social Assistance in Indonesia: Social Assistance Program and Public Expenditure Review 8. Jakarta: The World Bank Office.

World Bank. 2012b. Protecting Poor and Vulnerable Households in Indonesia. Jakarta: The World Bank Office.

World Bank. 2014. Indonesia: Avoiding the Trap. Jakarta: The World Bank Office.

World Bank. 2015. Taxes and Public Spending in Indonesia: Who Pays and Who Benefits? Jakarta: The World Bank Office.

World Bank. 2016. Indonesia's Rising Divide. Jakarta: The World Bank Office.

World Bank. 2017. Towards a Comprehensive, Integrated, and Effective Social Assistance System in Indonesia. Jakarta: The World Bank Office.

Yulaswati, Vivi, and Pungky Sumadi. 2011. Reducing Poverty by Increasing Community and Female Participation. In Employment, Living Standards and Poverty in Contemporary Indonesia, ed. Chris Manning and Sudarno Sumarto, 291-312. Singapore: Institute of Southeast Asian Studies.

Yusuf, Arief Anshory, and Andy Sumner. 2015. Growth, Poverty and Inequality under Jokowi. Bulletin of Indonesian Economic Studies 51 (3): 323-348.

Yusuf, Arief Anshory, Andy Sumner, and Irlan Adiyatma Rum. 2014. Twenty Years of Expenditure Inequality in Indonesia, 1993-2013. Bulletin of Indonesian Economic Studies 50 (2): 243-254.

Open Access This chapter is licensed under the terms of the Creative Commons AttributionNonCommercial-NoDerivatives 4.0 International License (http://creativecommons.org/licenses/bync-nd/4.0/), which permits any noncommercial use, sharing, distribution and reproduction in any medium or format, as long as you give appropriate credit to the original author(s) and the source, provide a link to the Creative Commons license and indicate if you modified the licensed material. You do not have permission under this license to share adapted material derived from this chapter or parts of it.

The images or other third party material in this chapter are included in the chapter's Creative Commons license, unless indicated otherwise in a credit line to the material. If material is not included in the chapter's Creative Commons license and your intended use is not permitted by statutory regulation or exceeds the permitted use, you will need to obtain permission directly from the copyright holder.

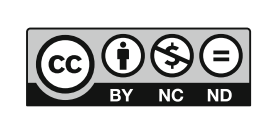

